THE COSMIC WEB 



\title{
THE COSMIC WEB
}

\section{Scientific Field Models and}

Literary Strategies in the Twentieth Century

\section{N. Katherine Hayles}

\author{
Qi \\ CORNELL UNIVERSITY PRESS \\ ITHACA AND LONDON
}


Open access edition funded by the National Endowment for the Humanities/ Andrew W. Mellon Foundation Humanities Open Book Program.

\section{Copyright (C) 1984 by Cornell University}

All rights reserved. Except for brief quotations in a review, this book, or parts thereof, must not be reproduced in any form without permission in writing from the publisher. For information, address Cornell University Press, Sage House, 512 East State Street, Ithaca, New York 14850, or visit our website at cornellpress.cornell.edu.

First published 1984 by Cornell University Press

Library of Congress Cataloging-in-Publication Data

Hayles, N. Katherine.

The cosmic web : scientific field models and literary strategies in the twentieth century.

Bibliography: $p$.

Includes index.

1. Literature, Modern - 20th century-History and criticism. 2. Literature and science. I. Title.

PN771.H36 $1984 \quad 809 ' .93356 \quad 84-45141$

ISBN-13: 978-0-8014-1742-9 (cloth) — ISBN-13: 978-0-8014-9290-7 (pbk.)

The text of this book is licensed under a Creative Commons

Attribution-NonCommercial-NoDerivatives 4.0 International License:

https://creativecommons.org/licenses/by-nc-nd/4.0/ 
For TRURL 
